\title{
Political Citizenship: Exploring the Precept of Acceptance of State Legitimacy Through Indian Independence Movement
}

\author{
Dr R Srinivasan ${ }^{1}$
}

\begin{abstract}
The concept of citizenship is central to any discourse on society, state and sovereignty. Though the meanings and content of citizenship have evolved over time through interactions between society and state, the anatomy of such interactions has not invited scholarly exploration in the Indian context. The discourses in this dimensions have remained centered on Rights-andObligations approach perhaps due to the colonial conceptions of state, though commencing from the colonial times, social action and social movements have made important newer meanings into the concept of citizenship.
\end{abstract}

Drawing from RJ Dalton's study of political citizenship, this paper adopts an explorative methodology to validate a theoretical precept, that acceptance of state legitimacy or otherwise, played an important role in shaping the concept of citizenship in the colonial society. By doing so, the paper attempts to provide a theoretical framework for study of citizenship in postcolonial societies.

Keywords: Citizenship, social movement, legitimacy of state, colonial India, post-colonial society, Rights and Duties

\footnotetext{
${ }^{1}$ Dr R Srinivasan is an independent researcher and Editor-in-Chief of Electronic Journal of Social and Strategic Studies.
} 


\section{Political Citizenship: Exploring the Precept of Acceptance of State Legitimacy Through Indian Independence Movement}

\section{Introduction}

Political philosophers from the time of Bodin and Hobbes have set the parameters of citizenship within the confines of 'Rights and Duties' since they upheld sovereign power of state to be supreme. The state as a being demanded that individuals surrender their liberties to the extent the interest of state could prevail. The dialogue on rights or more appropriately, human rights, was seen as a concession that the state would consent to grant. Even though the French Revolution expounded the concepts of Liberty, Equality and Fraternity, these concepts were seen as subordinate to what the state would legislate. State citizenship laws generally tended to see citizenship within the precincts of either of the two principles viz., jus sanguinis or jus solis (based on the principle of blood, descent or heritage or simply on birth).

Baylis and Smith ${ }^{\mathrm{i}}$ define citizenship as "the status of having the right to participate in and to be represented in politics". It is a collection of rights and obligations that give individuals a formal juridical identity. T.H. Marshallii, whose work has long dominated the debates about social citizenship, considered citizenship as:

"a status bestowed on those who are full members of a community. All who possess the status are equal with respect to the rights and duties with which the status is endowed".

Scholarly attention to both citizenship and social movements developed as full-fledged disciplines from 1960. Some of the major reasons for such academic interest were the birth of various movements like black students agitation for equal rights on campuses and anti-war (Vietnam) demonstrations in USA; May 1968 Revolt in France; 1969 'Hot Autumn' in Italy and pro-democracy agitations in Franco's Spain and communist Prague. These were also a period in which all over the world, women's rights movements and environmental movements were born to demand equality for women in social space and responsible use of ecological resources. These civil rights, environmental and students' movements from early 1960s to late 1990s lead to the development of three distinct notions of citizenship as against

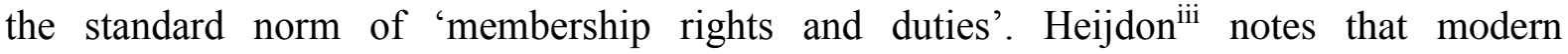
citizenship rights drawing from the nation-state typically include civil rights (free speech and movement, the rule of law); political rights (voting and seeking electoral office); and social citizenship rights (welfare, unemployment insurance and health care). In fact, the new crop of 
social movements across the western world led Meyer and Tarrow ${ }^{\text {iv }}$ to tag the western society as a 'social movement society'. Russell Dalton ${ }^{\mathrm{v}}$ further observed that these movements played a pivotal role in the further development of the concept of political citizenship. In his classical study of political citizenship and social movements, Dalton ${ }^{\mathrm{vi}}$ identifies four broad principles that are intertwined with the concept of citizenship:

"First, public participation in politics is broadly considered to be a defining element of democratic citizenship (Dahl, 1998; Pateman, 1970; Verba et al., 1995). Unless citizens participate in the deliberation of public policy, and their choices structure government action, then democratic processes are meaningless. Often this presumes participation in free and fair elections that select government officials, but the range of political participation can be, and should be, much broader. Thus, the norm of political participation should be an essential element of democratic citizenship.

A second related category taps what has been called autonomy (Petersson et al., 1998). Autonomy implies that good citizens should be sufficiently informed about government to exercise a participatory role. The good citizen should participate in democratic deliberation and discuss politics with other citizens, and ideally understand the views of others. Robert Dahl (1998) and others have discussed how access to information and the free debate of opinions is essential to produce meaningful democratic participation. Other researchers have described such items as representing critical and deliberative aspects of citizenship (Denters et al., 2007).

Philosophical discussions sometimes overlook the commitment to social order and the acceptance of state authority as essential elements of citizenship. Even democratic governments emphasize the role of the loyal law-abiding individual as a prime criterion of citizenship. Indeed, acceptance of the legitimacy of the state and the rule of law is often the implied first principle of citizenship, since without the rule of law meaningful political discourse and discussion cannot exist. Political philosophy is replete with those who stress the acceptance of state sovereignty - from Bodin to Hobbes to Hamilton even before the participatory elements of democracy.

A fourth potential element of citizenship involves relation to others in the polity. T. H. Marshall (1992 [1950]) described this as social citizenship. The expansion of civil and political rights led to new categories of social rights, such as social services, providing for those in need and taking heed of the general welfare of others. Citizenship thus may 
include an ethical and moral responsibility to others in the polity, and beyond. The framework of distributive justice provides a theoretical base for equality as a basis of citizenship. Unless individuals have sufficient resources to meet their basic social needs, democratic principles of political equality and participation lack meaning. Although initially identified with the European welfare state and social democratic critiques of capitalism, this idea of citizenship has been embraced by liberal interests in America (Shklar, 1991; Walzer, 1983)".

An inclusive definition of citizenship therefore reveals five dimensions of participation, informed engagement, commitment to social order, acceptance of state legitimacy and right to distributive justice. While all these elements of citizenship evolved through the ages, accepted and incorporated in the constitutional mandates of modern democracies, they still preclude an important element of citizen engagement. The sixth dimension to citizenship therefore is an engaged citizenship. The 'engaged'vii citizenship adds an important dimension to political rights. From being vested with the mere power to vote or compete for an electoral office, an 'engaged' citizen exercises the right participate in naysaying actions as a form of his political expression. In doing so he conveys his dissatisfaction with the status quo and also attempts to influence the political decision in ways that address his concerns. When an 'engaged' citizen influences the political process within the confines of his commitment to social order and legitimacy of state, we may say he acts as a 'political citizen' or exercises his political citizenship.

In the structural space, the role played by UN in promoting citizenship rights beyond its conventional meaning also needs to be understood. In 1945, the UN adopted the Universal Declaration of Human Rights (UDHR). UDHR became the clarion call to states to recast their constitutional mandates so as to universalize rights that were hitherto considered the prerogative of the state. For example, the right to assembly (Art. 20), right to take part in the government of the country (Art.21), right to social security (Art. 22), right to work (Art.23), etc., redefined what citizenship meant. The universal acceptance of UDHR further led to the adoption of ICESCR and ICCPR 1966 expanding the dimensions of rights as well as duties that fall within the ambit of citizenship. The implication of the rights expounded by UN instruments have had dual impact: the new nations that were born after the WW II drafted their constitutions incorporating these rights into their political structure and armed with the knowledge that these rights are obtainable ${ }^{\text {viii, }}$, oppressed and hitherto colonized populations demanded the translation of these rights into practices which in turn led to newer social 
movements espousing them. Academic discussions however, generally tend to overlook the impact of such resolutions and conventions of the UN born from collective human experience. To disregard them is akin to studying the Vedas without the aid of Sanskrit. We will still grasp the beauty of the meaning, but would miss out on the elegance of their prose.

\section{Independence Movement and Citizenship}

However, the discourses on citizenship became refined when social movements were born across the landscape. The discourses, as mentioned earlier were on different lines till about 1960. With the advent of social movements, scholars like Dalton, Daniella De Porta, Habermas, Gaventa, McAdam, Tilly, and Tarrow, social scientists and political pundits came together to redefine the concept of citizenship that evolved owing to the impact of social movements. The role played by women's' movements, students' movements, environmental movements and pro-democracy movements in expanding the meaning of citizenship is monumental.

In the Indian context, social movements have also played a critical role in advancing the meaning of citizenship, though as Ghanshyam Shah ${ }^{\mathrm{ix}}$ observes that the study of social movements have generally been historiographical. The impact of social movement action on citizenship has generally been drowned in the fervent clamor to tag them as freedom movements, farmers' rebellion, etc. In the enthusiasm to typologize them, their political impact has been unfortunately given a back seat.

A study of social movements in India of modern times will necessarily begin with the independence movement of early $20^{\text {th }}$ century. The independence movement was not a single continuous movement spanning five decades, but rather composed of many movements at different points of time like the Swadeshi Movement (1905), the Dandi March (1930), and the Quit India Movement (1942). Each of these movements produced a slew of effects on the civil and political rights of Indian citizens of the Empire like the Swadeshi movement gave rise to cottage and other industries resulting in rise in employment and economic advancement; the Dandi march re-asserted the right to produce basic necessities and in the wake of concerted agitations that followed, the enactment of Government of India Act 1935 paved the way for Provincial Elections (therefore, right to vote); Quit India movement eventually resulted in independence, asserting the highest political right of self-determination. These movements were guided by the Gandhian philosophy of non-violence which defied British authority without use of force. 
Does the quest for freedom and thereby, self-determination, qualify as an attribute of or define citizenship? Even though this question may appear incongruous in the light of accepted scholarly opinions that house civil, political and economic rights within the concept of citizenship, in view of the ethos propounded by leaders like Mahatma Gandhi, it is necessary to attempt an answer. The most eloquent answer would perhaps be found in Gandhi's defense when he was accused of sedition by promoting disaffection among the people of India through his writing in Young India ${ }^{x}$, in the trial of 1922. In his statement in defense, Gandhi stated $(\text { Agarwala, 1991) })^{\mathrm{xi}}$ :

I discovered that as a man and as an Indian, I had no rights; more correctly, I discovered that I had no rights as a man because I was an Indian....

In fact, I believe that I have rendered a service to India and England by showing in noncooperation the way out of the unnatural state in which both are living. In my humble opinion, non-cooperation with evil is as much a duty as is cooperation with good. But in the past non-cooperation has been deliberately expressed in violence to the evil-doer. I am endeavoring to show to my countrymen that violent non-cooperation only multiplies evil and that an evil can only be sustained by violence. Withdrawal of support of evil requires complete abstention from violence. Non-violence implies voluntary submission to the penalty for non-cooperation with evil. I am therefore to invite and submit cheerfully to the highest penalty that can be inflicted upon me for what in law is a deliberate crime, and what appears to me to be the highest duty of a citizen.

Gandhi's statement brings out two elements: authority of the colonial state is coercive by definition and dehumanizing limitations were imposed by the state on the rights of citizens. Under both these conditions, citizenship based on the principles of jus sanguinis or jus solis are rendered hollow. Under such conditions, Gandhi considered challenging the legitimacy of state as an essential duty of citizenship.

It must also be noted that the independence movement was not merely the one under the leadership of Indian National Congress. There were other movements led by Bal Gangadhar Tilak, Annie Beasant, Lala Lajpat Rai, Bipin Chandra Pal, Vir Savarkar, Aurobindo, Khudi Ram Bose and later Netaji Subhash Chandra Bose that at some point of time merged into or remained at variance with that of the Indian national Congress. These parallel movements subscribed to even violent methods to challenge British authority. The tactics and methods 
adopted by these movements actually merit examination from the perspective of political citizenship.

At least two important studies by MR Frost (Frost, 2018) ) $^{\mathrm{xi}}$ and Inamdar (Inamdar, 1985) point to the fact that the Home Rule movement under Tilak, Beasant and Lala Lajpat Rai adopted agitation as a tool to obtain equality for the Imperial Indian subjects with those of white British subjects initially. When Home Rule movement eventually merged with the Indian National Congress, the modes of their agitation adopted the principle of non-violence, while earlier they were not necessarily averse to it. As MR Frost points out, the political citizenship content of such movements in colonial societies remain little studied as compared to the larger political movements. Scholarly attention on the larger movements also largely limited to a nationalist or historiographical approach instead of the citizenship aspects.

Even in the case of violent and armed struggle adopted by Subhash Chandra Bose by forming the Indian National Army and engaging the British through armed might in conjunction with Imperial Japan, the raison d'etre for the struggle was not to challenge the British Crown, but to obtain for people of India the rights and opportunities that free citizens enjoy in other national territories. Dr RC Roy (Roy, 2004) ${ }^{\text {xiv }}$, while studying the social, economic and political philosophy of Subhash Chandra Bose finds the following:

The concept of human freedom has changed. In ancient times, by freedom people of India meant spiritual freedom - renunciation, freedom from lust, greed etc. But this freedom also included freedom from political and social bondage." Subhas's emphasis on individual is dignity, and identity did never allow him to accept the totalitarian doctrine that "State is the Master, the Individual the Servant." Although in need of "a political system - a state of an authoritarian character" in place of a "So called democratic system" he meant a State, "It will work as an organ or as the servant of the masses ... the servant of the people." "The political foundation of democratic philosophy is the supremacy of the people as the source of authority." Due to the influence of Swami Vivekananda, Subhas had developed immense faith in the power of the people, which is evident from his letter dated 23.3.1920 written from Cambridge to his friend Charu Chandra Ganguly

When the tactics of these movements is tested against the Dalton-ist benchmarks of political citizenship, we find that the challenge to state legitimacy was a criterion that stands out. The Gandhian tactics used moral authority to compel the state to grant concessions like the 
Montagu-Chelmsford Reforms resulting in Government of India Act 1919; granting the right to elect representatives of people, even though limited in its ambit; or, the Government of India Act 1935 paving the way for elected Provincial governments. In contrast, the violent movements launched against British authority by others like Tilak, Lala Lajpat Rai, Subhash Bose or Vir Savarkar invited brutal repressions, trials for treason and deportation. When we set aside the nationalistic or patriotic content and look at these movements from political sociology perspective, it is evident that state legitimacy or the challenge to state legitimacy played a crucial part in the ability of the movement to shape citizenship ${ }^{\mathrm{xv}}$.

\section{Conclusion}

In the strictly patriotic context though, it could be argued that challenging the legitimacy of the colonial state is merely an attempt at re-defining 'colonial citizenship'. However such view or an argument is not tenable since the notion of citizenship is applicable only within the context of a sovereign independent state, for the state and citizenship have an umbilical relationship. Without both of the conditions, that is a free sovereign state and freedoms associated with citizenship complementing each other, the notion of 'colonial citizenship' is but an illusion.

In his investigation of the nebulous connection between the state and citizenship in African Post-Colonial Societies, Small (Small, 1977) ${ }^{\mathrm{xvi}}$ finds that the ideals of citizenship in colonial societies created within borders drawn by occupying powers are essentially different from the ideals of citizenship in post-colonial societies. He further identifies the challenges in postcolonial sovereign nations with reference to evolving newer ideals in the following words:

The purpose of citizenship ideal in this situation (Colonial Societies) is to articulate a sense of nationhood in a territory that has political unity but little else. From the precolonial situation come differences of peoples, language, culture, subsistence; from colonial situation come differences due to educational and economic development, overlaying and distorting the pre-colonial disparities. It is for the independent governments to attempt to reconcile these differences (P.18).

Even though the ideal of citizenship in a colonial context is at variance with those in an independent society, the freedom movement in India as well as in other parts of the colonial world show that challenging the legitimacy of state by political movements fundamentally revolved around the concept of citizenship. In Gandhi's eloquent words, the struggle for freedom (therefore the fundamental freedoms associated with citizenship) is 'the highest duty of a citizen. In the same vein, Subhash Chandra Bose's 'supremacy of the people as the source 
of authority' again reverberates with Abraham Lincoln's concept - of the people, by the people and for the people - a foundational construct of democracy and freedom.

Challenging the legitimacy of the state is not merely a precept of political citizenship validated through India's independence movement. In the post-independent society too, a number of movements typologised by scholars like Ghanshyam Shaw, MS Rao, etc as peasant movements, environmental movements, human rights movements, etc., have played critical role in expanding the concept of citizenship. In the political and civic rights dimension, the anti-corruption movement led by Anna Hazare in 2011 was catalytic to the Lok Ayukta and Lok Pal Bills in the India Parliament addressing the crucial transparency-accountability issue in governance. Even in USA, the recent Black Lives Matter is one such rights movement that calls for scholarly scrutiny in so far as political citizenship and its contents are concerned.

Perspective and analytical studies into these movements would substantially contribute to the understanding of social dynamics and citizenship content in free societies. Their findings will help evolve what we may call as 'proofing against predatory governance' ${ }^{\text {xvii }}$ which is not unique only to societies governed by colonial or dictatorial regimes.

\section{References/End Notes}

\footnotetext{
${ }^{\text {i }}$ Baylis, J \& Smith, S (2001). The Globalisation of World Politics. An introduction to international relations. OXford, New York: Oxford University Press.

ii Marshall, TH (1950). Citizenship and Social Class, and Other Essays. Cambridge (UK): The University Press.

iii Heijden, H-AV (2014). Introduction: Linking Political Citizenship and Social Movements. In H-AV Heijden, Handbook of Political Citizenship and Social Movements (pp. 1-25). Cheltenham: Edward Elgar Publishing Ltd.
}

${ }^{i v}$ Meyer, DS \& Tarrow, SG (1998). The social movement society: contentious politics for a new century. The University of Michigan: Rowman \& Littlefield Publishers.

${ }^{v}$ Dalton, RJ (2015). The Good Citizen: How a Younger Generation Is Reshaping American Politics (Vol. 56). Washington DC: Congressional Quarterly Inc.

${ }^{v i}$ Dalton, RJ (2008). Citizenship Norms and the Expansion of Political Participation. Politicl Studies, 56(1), 76-98.

vii "Engaged citizenship taps participatory norms that are broader than electoral politics. The engaged citizen is more likely to participate in boycotts, buying products for political or ethical reasons, demonstrations and other forms of contentious action (Dalton, 2008)". 
viii Whereas it is essential, if man is not to be compelled to have recourse, as a last resort, to rebellion against tyranny and oppression, that human rights should be protected by the rule of law (Preamble to UDHR 1948)

${ }^{\text {ix }}$ Shah, G (2004). Social Movements in India: A Review of Literature. New Delhi: Sage Publications India Pvt Ltd.

${ }^{x}$ Young India was a newspaper published by Shankerlal Ghelabhai Banker, and Mahatma Gandhi was its Editor.

xi Agarwala, BR (1991). Trials of Independence 1858-1946, National Book Trust of India: New Delhi, P.99

${ }^{x i i}$ Frost, Mark R. (2018) Imperial Citizenship or Else: Liberal Ideals and the India Unmaking of Empire, 1890-1919, The Journal of Imperial and Commonwealth History, 46:5, 845-873, DOI: $10.1080 / 03086534.2018 .1519243$

xiii Inamdar, N. (1985). TILAK AND THE INDIAN NATIONAL CONGRESS. The Indian Journal of Political Science, 46(4), 387-400. Retrieved May 28, 2021, from http://www.jstor.org/stable/41855194

${ }^{x i v}$ Roy, Dr RC (January 2004). Social, Economic and Political Philosophy of Netaji Subhas Chandra Bose, Orissa Review, Govt. of Odisha, P 8. Retrieved from: https://magazines.odisha.gov.in/Orissareview/jan2004/englishpdf/chapter1.pdf Accessed 05 April 2021.

${ }^{x v}$ In the patriotic context though, it could be argued that challenging the legitimacy of the colonial state is an attempt at re-defining 'colonial citizenship'. We are of the view that such an argument is not tenable since the notion of citizenship is applicable only within the context of a sovereign and independent state and 'colonial citizenship' was devoid of rights such as right to life, right to expression, etc.

${ }^{x v i}$ Small, N. (1977). Citizenship, Imperialism and Independence: British Colonial Ideals and Independent African States (1st part) / CITOYENNETE, IMPERIALISME ET INDEPENDANCE: IDEAUX DU COLONIALISME BRITANNIQUE ET PAYS INDEPENDANTS D'AFRIQUE. Civilisations, 27(1/2), 17-43. Retrieved May 29, 2021, from http://www.jstor.org/stable/41803084

xvii 'Proofing against predatory governance' is a concept that may be defined as the rule of law framework used by a regime in power in a country that deliberately and intentionally denies equality in the enjoyment of fundamental freedoms - of expression, of worship, right to life and right to livelihood - to any or specific segment of the society in the territory under its authority on the basis of a discriminative yardstick. When such a regime is prevented or strongly discouraged from such discriminate exercise of authority through legislative, judicial or even through the intervention of international community, we may say proofing against predatory governance prevails. For example in India, $44^{\text {th }}$ Constitutional Amendment was adopted to prevent the unilateral usurpation of fundamental rights as was evidenced through $42^{\text {nd }}$ Amendment by Indira Gandhi in 1976. The object of the $44^{\text {th }}$ Amendment clearly states:

Recent experience has shown that the fundamental rights, including those of life and liberty, granted to citizens by the Constitution are capable of being taken away by a transient majority. It is, therefore, necessary to provide adequate safeguards against the recurrence of such a contingency in the future and to ensure to the people themselves an effective voice in determining the form of government under which they are to live. This is one of the primary objects of this Bill. 
Please see: Government of India, My Government, The Constitution (Forty-fourth Amendment) Act, 1978, at: https:/www.india.gov.in/my-government/constitutionindia/amendments/constitution-india-forty-fourth-amendment-act-1978 